\title{
AN ANALYSIS OF SLANG LANGUAGE TYPES IN "THE DUFF" MOVIE
}

\author{
Heppy Sinaga ${ }^{* 1}$, Herman ${ }^{* 2}$, Christian Neni Purba ${ }^{* 3}$, David Togi Hutahaean ${ }^{* 4}$ \\ fukadaherman@gmail.com/herman@uhn.ac.id ${ }^{* 2}$, bochubojg2@gmail.com ${ }^{* 3}$, \\ davidhutahaean138@gmail.com ${ }^{* 4}$ \\ Undergraduate Student of English Education Department*1, \\ English Education Department ${ }^{* 2,3,4}$ \\ University of HKBP Nommensen, Medan, Indonesia ${ }^{* 1,2,3,4}$
}

\begin{abstract}
The purpose of this study was to determine the type of use of slang language. The types of slangs were analyzed from "The Duff" movie. Theories used in this research were Paltridge (2004) about the types of slang language and Yanhong (2013) about the functions of slang. This study was conducted using a descriptive qualitative method. The data were from a movie entitled "The Duff" in the year of 2015 with a genre of teen or comedy. After conducting the analysis, this study showed that there were six slang languages from eleven types of slang language. They were society, cockney, workmen's, public school and university, public house, and theater. Society was found as the most dominant slang language with society with 41 data(54,6\%), public house with 20 data $(26,6 \%)$, workmen's with 6 data $(8 \%)$, cockney with 5 data $(6,6 \%)$, theater with 2 data(2,6\%), and public school and university with 1 data $(1,3 \%)$. Finally, the researcher hopes that this study will be useful for the future improvement of studying literature, especially about slang language
\end{abstract}

Keywords: Functions, movie, slang language

DOI: https://doi.org/10.31943/wej.v4i1.69

\section{INTRODUCTION}

In our environment, if we want to communicate each other, we need to use language as the tool to express our feeling, thoughts, or ideas. Language is the way we want to share something with others. Language has function if there are speakers, researchers, listeners, and readers.

According to Fromkin (1974), Language has a characteristic flexible and dynamic it means for time to time, it will grow and change, which will create a new assumption in communication, so it is impossible that language just can stop in one word and one meaning. A lot of kinds of language in the world but as we know English is the one language that to be used as an international language when people want to go abroad they can use English as their tool to communicate with each other without hesitation. English also becomes the language of standardization for many countries to become their national language. It has been divided into two parts, standard English and Non-standard English. Standard 
English is a variety of English that is usually used in printing and speaking, which is normally taught in school or in a deliberate manner, also spoken by educated people. (Wardhaugh, 1986).

Spolsky (1998) stated that Standard English has colloquial as well as formal variants. On the other hand, Non-standard English is properly using in a particular situation and cannot be used in a formal case and usually spoken by uneducated people. There are many kinds of non-standard languages, one mark of non-standard English that is used on informal style is slang. Slang is considered a very informal word or expression that is commonly used in our everyday conversation. Even though the use of slang is really popular nowadays, in the past, slang was often associated with vulgar words that were considered nonstandard language. In general, the use of slang is really popular and appears anytime and in all languages, slang also has some type. It is interesting to conduct a research, especially for slang, because it will give additional information.

The use of slang can also be found in lyrics and movies. Especially lyrics and movies that bring out the social and cultural side of someone's identity. To analyze the slang, the researchers use the movie " The Duff" as a source of research material by watching the movie with subtitles. The movie "The Duff" or "Designated Ugly Fat Friend" it's about comparing yourself to other people around you, especially in your friend group. In the film, after Bianca (Mae Whitman) tosses a drink on Wesley (Robbie Amell) for dubbing her a "DUFF," he takes some time to explain what he means. One of his examples is pointing out a pretty blonde at the party as a "DUFF," which Bianca is astounded at because the girl is gorgeous. But compared to her group of friends who all look like models, he explains, she feels like the ugly duck. Everyone is always going to feel like someone has sexier legs or prettier eyes or better hair than them, but you're the one making yourself the "DUFF" — your friends shouldn't see you that way if they're true pals.

This movie doesn't just apply to women, either. From macho jocks like Wesley to their teacher Mr. Arthur (Ken Jeong) to a group of self-proclaimed band geeks, there's a "DUFF" in every group. It's not because all of their friends make fun of them behind their backs in those cases, but about the way they perceive themselves. Sure, you may not be the most muscular guy on the football team or you may have hit puberty a little late, but that doesn't mean you should be any less happy with yourself. Everyone is unique, and what makes you so special is not being like everyone else. It may sound cheesy, but it's a good mantra to live by - and one that The DUFF supports.

In the slang, dictionaries are included on the newest slang words that have been studied by linguistics and then analyzed in detail to ensure the meaning, spelling, and grammar. Slang dictionary contains terminology, definitions, pronunciation, usage in sentences, as well as the origin of the word. In slang 
language, there are some types sometimes, and we don't know the type of slang language. Here the researcher use "The Duff" movie as a source of research, and conduct a research entitled An Analysis of Slang Language Types in "The Duff" Movie.

\section{LITERATURE REVIEW}

\section{Language Phenomena}

Language is always changing, evolving, and adapting to the needs of its users. As long as the needs of language, users continue to change, so will the language. But reading Shakespeare's writings from the sixteenth century can be difficult because there are many words from the sixteenth century that we never heard again (Betty: 2012). The simple example is the use of word thy and thou. Nowadays, the word thy and thou have shifted with the word you.

Nowadays, many people use slang in their daily life. Whereas slang was once considered as the lowest form of communication, many people now consider slang to be an intelligent and insightful variation to the standard language.

\section{Slang}

Slang is an informal expression used usually in conversations. Eble (1996) as cited in Purba, Herman, and Purba (2019:3) stated that slang can be defined as a collection of everyday languages that constantly change the words and phrases used by speakers to build or strengthen cohesive social identity in a group or with trends or fads in society in general. The use and the words combining a slang are highly influenced by the culture and the traditions of a particular place, community, or group.

As Holmes (2001) states that people in a society may speak some varieties of language by a different social situation they meet. People should indeed know whether they are in an informal or formal situation. When people speak, they should understand well about a situation in and around. It is important in choosing appropriate language that will be used, formal style, or non-formal one. The use of slang language can be affected by some social factors such as age, gender, status, etc. Slang is another area of vocabulary which reflects a person's age (Holmes, 2001; 167).

According to Claire (1998: 15), slang is a term that is used by people in a social situation where they feel comfortable with their friends. Slang is usually used in a non-formal situation. It can make a conversation becomes more intimate. Slang term is used in almost all oral language and usually used to express people's feelings and creativities. Slang is a variety of language that is used by a restricted part of the population, often younger or "less respectable" than the majority, and is based on a very informal or very innovative lexicon that replaces other words available in the general lexicon. So, we can conclude that slang is a non-formal or casual spoken language which created and used by a member of a certain community and usually used informal situations.

\section{Types of Slang}

Partridge (2004: 204) clarified that there are eleven types, there are: 


\section{a. Cockney Slang}

Cockney slang is in the form of English slang, which originated from the End East of England. At first, cockney slang only used by the working class in England. But nowadays, most of all people in England use cockney slang, especially in London. This slang has been popularized by film, music, and literature.

Below are some examples of Cockney slang which taken from a book" $A$ Dictionary of Slang and Unconventional English" by Partridge (2006):

- Airy-fairies means (large) feet

- Back double means a back street

- Goshermeans a heavy blow or punch

These examples categorized as cockney slang because all of them are discovered in British, where cockney is commonly used.

\section{b. Public House Slang}

The definition of public house slang is considered as public house group of words or phrases that make up for the smallness of the recorded vocabulary by the nature of the subject. It is genial, cheery, materialistic, but not gross nor cynical. The examples are taken from "The Routledge Dictionary of Historical Slang" by Partrige (2006):

- Booze-shutter means a beer drinker.

- War Cry means a mixture of stout and mild-ale understood.

The term, "booze-shunter" used by the South-Western porters and guards who frequented the pubs around Waterloo station, originated the term, which soon became general among the police officers society, while the term "war-cry" has a satirical reference to the salvation Army, which speaks stoutly in polite language.

\section{c. Workmen's Slang}

This type of slang has a link with a public house's slang, yet, there is a difference between them. The characteristics of the users of workmen's slang do not mention the real "something," but they call it with another name that already used and understood among them. For example, workmen from mining or ironworks will say brass instead of money. The examples below were taken from a book “A Dictionary of Slang and Unconventional English" by Partridge (2006):

- Jumping Jinny, means a mechanical stamper used in road-repairs

- Bank up means to complete a liberal scale, to reinforce generously, to lay in a mighty store.

The term "jumping Jinny", was found around a year of 1920. This slang even used by The London Evening News, 7 December 1936. While "bank up" used for the first time in 1896 by labor in North of England.

\section{d. Tradesmen's Slang}

In tradesmen's slang as in workmen's slang, some words are related to origin slang, and the users are the workmen too. But, the difference is there are 
four typical users of tradesmen's slang: tailors, butchers, chemist, and builders. The tailors have the largest number of slang terms. The examples below were taken from book "slang: Today and Yesterday" by Partridge (2004):

- Tradesmen's slang for tailors: house of parliament, means a meeting of tailor's assistant and apprentices in the shop, especially for a serious purpose.

- Tradesmen's slang for builders: flannel jacket, means the navy on heavy work has long and so unexceptionally worn flannel.

These slangs categorize as tradesmen's slang because each of these slangs shows the characteristics that belong to tradesmen's slang.

\section{e. Slang in Art}

Slang in art is still related to society. Words or phrases if slang in art are quickly adopted by society, although there are only a few words known as artistic slang. According to Partridge (2004: 221), slang in art appears in the seventeenthcentury when slang was brought in the stage for the first time in Richard Brome's comedy A Fovial crew. Furthermore, this slang is considerably more difficult than other slang terms. The meaning is so difficult to guess in the present day. The examples below were taken from a book "A Dictionary of Slang and Unconventional English" by Partridge (2006):

- Drawing means a picture in water-color.

According to Partridge (2004: 340), the term "drawing" was discovered in 1870 by Barrere and Leland. While according to the explanation in a book " $A$ Dictionary of Slang and Unconventional English".

\section{f. Slang in Publicity}

This type of slang is often used for commencing because much of modern commerce depends on publicity, a firm needs the catchy phrase or rhymes that can impress the public. The examples below were taken from a book "A Dictionary of Slang and Unconventional English" by Partridge (2006):

- In do a Garbo, means to avoid Press reporters and photographers and publicity.

- Worth a guinea a box means a small, cheap, yet goog or useful article.

The term "in do a garbo" was used for the first in 1925, but nowadays, this slang is never heard again. The slang word "worth a guinea a box" is derived from the considerably older slogan of Beecham's Pills.

\section{g. Slang in Theatre}

Slang in theatre is related to slang in art because theatre is on art of term. According to Partridge (2004), slang used for the first time on stage in the sixteenth century. Theatre slang begins to develop in the nineteenth century and expands its influence on ordinary and informal spoken English. Therefore, theatrical slang little by little gained a status in the first part. For example, the Roman researchers Plautus, Horace, Juvenal, and Petronius used slang for stylistic purposes and Shakespeare also used slang in his plays. 
Below is the examples of theatrical slang which are taken from a book "Slang: To-day and Yesterday" by Partridge (2004):

- An acting lady means an incapable actress. From the poor acting of the great majority of society, women, and girls that go on stage.

- Paper house means theatre that at a given performance has an audience consisting mainly of those who have come with "paper" complimentary ticket.

These examples include in the theatre's slang based on the characteristics of the word connected to its theory.

\section{h. Slang in Public School and University}

The main source of this slang is student because they are fresh and full of creativity. Every school has its own special words known to no other school. The examples of public school slang below were taken from a book "A Dictionary of Slang and Unconventional English" by Partridge (2006):

- Bonse means head, for example, " lookout, or I'll fetch you a whack across the bonse

- Bung, means a lie, for example, "everything he said is a bung."

- What's the mat? means what's the matter?

\section{i. Society Slang}

Society slang is commonly used daily speaking and connected to society. Every society group uses some types of slang and by association, those words or phrases become property that belongs to that group, such a damn, shit, bitch, etc. In the modern world, slang has become so much defining trait of many groups that it is impossible to ignore the impact it has had on western society.

There are so many slangs in the colloquial speech of society, most of the words soon disappear, but a considerable number of them make good their place in ordinary speech. Moreover, society slang shows a joyously or jauntily over the object and practice of the slang user's own calling. The examples below were taken from a book "A Dictionary of Slang and Unconventional English" by Partridge (2006):

- Come the Rothschild, means to pretend to be rich.

- Repulsive means unpleasant dull.

The slang "comes the Rothschild" is derived from the legendary wealth of that famous family. This slang was found in 1880 but never used again in 1914. While the term "Repulsive" used for the first time in 1930 by Evelyn Waugh, in Vile Bodies, 'Isn't this a repulsive party?'

\section{j. Slang in Medicine}

Medical slang is slang used by doctors or nurse. The examples of this slang is very hard to find. According to Partridge (2004: 280), Ware gives fourterm used in 1999: bone-cloter, port winee, for which stout is now usually substituted as a "fattener"; locum (short for locum tenens) still very commonly employed by doctors and clergymen; pith, the spinal chord when severed; to be slated, to die, or more precisely to be doomed to die. Ware only has very few 
medical slangism list because doctors very rarely talk "shop" to others than doctors and because in the words of the one notable authority on medical slang. Below is the example of medical slang according to a book "A Dictionary of Slang and Unconventional English" by Partridge (2006):

- Lord have mercy (up) on me, mean he 'iliac passion', a'colic' of the small guts.

- Sciatic, means a sciatic nerve.

The slang "Lord have mercy (up) on me" appears for the first time in the sixteenth-century for medical used, according to Junius' Nomenclator, by 'the homelier sort of Physicians.' While "Sciatic" used for the first time by a young physician named E. F Brett Young in 1919. Based on the meaning and the explanation, these slangs include in medical slang.

\section{k. Soldier's Slang}

Soldier's slang is slang terms that come around the army community that is generally used by soldiers. In English-speaking countries, it often takes the form of abbreviations/acronyms or derivations of the NATO Phonetic Alphabet, or otherwise incorporates aspects of formal military terms and concepts. Military slang is often used to reinforce or reflect (usually friendly and humorous) interservice rivalries. The examples of this slang are:

- BOHICA stands for bend over here it comes again.

- FIGMO describes a person, especially one who has a short remaining time on station, who has a lax attitude toward their work.

BOHICA is an item of acronym slang which grew to regular use amongst the United States armed force during the Vietnam War. The acronym "FIGMO" stands for 'Fuck it, I've got my orders', or 'Finally I Got My Orders'.

\section{Functions of Slang}

Slang commonly uses to serve social purposes: to identify members of a group, tp exchange the level of discourse in the direction of informality, to oppose established authority. Sharing and maintaining a constantly changing slang vocabulary aids group solidarity and serves to include and exclude members. Slang is a linguistic equivalent of fashion and serves much the same purposes.

According to Yanhong (2013), there are three functions of slang, they are:

\section{a. The Pursuit of Self - identity}

Since different social and professional groups have different slang, thus it is considered as the symbol for dividing the professional groups in society. If somebody uses the words and expressions within a certain social group or professional group, he will blend with the group members from mentality. If a student says a sentence containing the special college slang, he must want to get the result of showing and strengthening the emotion that he belongs to the inside of the teenager group. 


\section{b. Emotive Feeling of the Slang Users}

The emotive function reveals the speaker's attitude towards his subject. The emotive function is one of the most powerful uses of language because itis so crucial and important in changing the emotional status of an audience for or against someone or something the emotive function helps us get rid of our nervous energy when we are under stress.

Psychologically, slang helps people to express their strong feeling, like group identification, and so on. When people use it, they want to show them against the reality and set them free psychologically. As Allen suggests, cited from Yanchun and Yanhong (2013), "Slang is a class of language, among other social and psychological uses, to deny allegiance to genteel, elite, and proper society and to its standard linguistic forms. "So that's why many people use slang in their conversation, from common people to intellectual groups, such as doctors, lawyers, and politicians. In this aspect, slang for them not only for stressing identity or group membership but also for the psychological need for expressing emotion, which is one of the basic functions of language as well.

\section{c. Achieving Politeness}

To discuss this topic, the term register needs to be mentioned. Register refers to "manner of speaking or writing specifically to a certain function, that is, characteristic of a certain domain of communication". The choice of register is affected by three factors, occasions ( formal or informal), an addressee (age, gender, occupation, the degree of familiarity), and the content of the conversation. Yanchun (2013) said that the use of slang is restrained by the three factors as well. Either the use of slang in improper occasions or the use of slang not to the right addressee, or the improper content in one's speech may ruin the friendship and good relationship with your interlocutors. Therefore, the proper use of slang facilitates setting up a certain atmosphere or maintaining social contacts. Slang is often used in informal occasions and is of importance in playing the phatic function. The use of slang can maintain friendship and harmony between our friends.

\section{RESEARCH METHODOLOGY Research Design}

The design of this research is a qualitative method because this research has several characteristics of qualitative. First, the research is natural because the researcher observed and collect the data in a natural setting, meaning that without manipulating the place, the time, the utterance was done by subject, etc. Second, the data in this research is a form of an utterance spoken by the character, which means that it is the form of words, not number. Third, this research is done inductively because the researcher analyzed the process, interprets, reports, and draws a conclusion from the process. In analyzing the data, the researcher uses the theory of slang language proposed by Partridge to determine the type of slang. 


\section{Data Source of Research}

This study is focused on the use of slang used in "The Duff" movie. The data of this research is utterance that pertinent with slang language. The data sources for this study are "The Duff" movie and transcript of the movie. Besides, the researcher also uses slang dictionary "Oxford Slang Dictionary" (1998) in searching the meaning of the word or phrase.

\section{Instrument of Research}

Because this research is to analyze the conversation, the research needs a good instrument to get the data. Such as laptop, internet, movie, and the best instrument for this research is human's instrument because it is the only instrument that is capable in doing this task. So, the researcher herself is the main instrument to collect and analyze the data as it is not possible to use other research instruments.

\section{Data Collection}

In getting the data, the research does several steps: first, the researcher finds the main data for her research data are "The Duff" movie and its transcript. The researcher gets the film and reads the transcript. Second, the researcher watches the movie and reads the transcript several times while searching for a slang language contains in the movie.

\section{Data Analysis}

After collecting the data, the research analyzes data based on the following steps: first, the researchers present the data. Second, the researchers categorize the data in an accordance with Partridge's theory about the type of slang. Third, the researchers choose "The Duff" movie because the researchers found many slang language in the movie. Fourth the research shows the type of the slang language and makes the meaning of that. Fifth, the researchers tabulate the data. The table consists of a slang word, duration movie, meaning that slang and type of slang.

\section{RESEARCH FINDING}

As mentioned in the objectives of the research, this research is aimed at identifying and analyzing the types of slang words that concise in "The Duff" movie. This chapter provides the result of this research which are divided into two parts, i.e., analysis and finding. In the analysis, discussing and explaining each category of slang words. Meanwhile, the data finding shows the appearance of the data, which is divided into two parts: the categories of Illocutionary Acts and the Function of Illocutionary Acts.

Data in this study is all utterance which is uttered in written form by "The Duff". The total number of the data are 75 data. There are eleven types of slang, according to Partridge, namely Society slang, Public house slang, Workmen's slang, Cockney slang, Art slang, Trademen slang, Public School, and University 
slang, Theather slang, Medicine slang, and Soldier slang. Hence, this movie found sixth categories of type slang which are society (41 data), cockney (5 data), workments' ( 6 data) public school and university ( 1 data), public house (20 data), and theater ( 2 data). In conclusion, there are 75 data found in the "The Duff" movie. The finding of types of slang in "The Duff" movie is illustrated in the following table in the following table 4.1

Table 4.1 Types of Slang in The Duff Movie

\begin{tabular}{|l|l|l|l|}
\hline No & Title of Movie & Type of Slang & Frequency \\
\hline \multirow{5}{*}{1} & \multirow{4}{*}{ The Duff } & Society & 41 \\
\cline { 3 - 4 } & Cockney & 5 \\
\cline { 3 - 4 } & Workmen's & 6 \\
\cline { 3 - 4 } & $\begin{array}{l}\text { Public School and } \\
\text { University }\end{array}$ & 1 \\
\cline { 3 - 4 } & Public House & 20 \\
\cline { 3 - 4 } & Theater & 2 \\
\hline \multicolumn{2}{|l|}{ TOTAL } & & 75 \\
\hline
\end{tabular}

Table 4.1 shows that the total numbers of data are 75 data from the movie containing a type of slang. In the table, we can see that the most dominant categories of type slang in the movie are society with 41 data(54,6\%), public house with 20 data $(26,6 \%)$, workments' with 6 data( $8 \%$ ), cockney with 5 data $(6,6 \%)$, theater with 2 data(2,6\%), and public school and university with 1 data $(1,3 \%)$.

\section{CONCLUSION}

Based on the findings and discussion in the previous chapter, the researcher concludes that there are six types of slang used in "The Duff" movie. First is society slang, second is public house slang, third is workmen's slang, fourth is cockney slang, fifth is a public school and university slang and the last is theatre slang. The researchers determine which slang include that slang by search its meaning in some dictionaries and understand the content of the dialogue.

Even the first time, slang word is known as an impolite and a rude language because it is used by criminals and the other lowest class of society. But, to along the growth of language, using slang language is one of the ways to enrich the study of language. Slang language is no longer a bad and impolite language, but it makes people more creative to convey something in a simple way.

\section{REFERENCES}

Birner, Betty. (2012). FAQ: Is English Changing?" (http:/www.lingusticsociety.org/resource/english-changing. Retrieved on June,20,2019) 
Claire, Elizabeth. (1998). Dangerous English 2000. USA: Delta Publishing Company

Fromkin, Victoria, \& Rodman Robert. (1974). An Introduction to language, second Australian Edition. New York: Holt Rinehart and Witson Inc.

Herman, Sinurat, B., Sitio, I.T. (2019). Ethnography of communication analysis in the short story of Romeo and Juliet. Education Journal, Volume 2, 2019. $P p$. 41-50. ISSN: $2617-4588$ DOI: $\quad$ 10.31058/j.edu.2019.23002. http://www.itspoa.com//UploadFiles/201910/369/2019102409470253079.pdf

Holmes, Janet. (2001). An Introduction to Sociolinguistics.London: Longman

Partridge, Eric. (2004). Slang: Today and Yesterday. London: Routledge and Kegan Paul Ltd.

Purba, A.J.M., Herman, and Purba, C.N. (2019). An Analysis of Indonesian Slang Words in Mojok Essay. European Exploratory Scientific Journal, Vol. 3, No. 3, PP. 01-08. Available at: https://www.syniutajournals.com/index.php/EESJ/article/view/81/73

Spolsky, Bernard. (1998). Sociolinguistics. New York: Oxford University Press.

Sitorus, E., and Herman. (2019). A Deixis Analysis of Song Lyrics in Calum Scott "You Are the Reason". International Journal of Science and Qualitative Analysis. Vol. 5, No. 1, 2019, pp. 24-28. DOI: 10.11648/j.ijsqa.20190501.14. Available at: http://www.sciencepg.com/journal/paperinfo?journalid=358\&doi=10.1164 8/j.ijsqa.20190501.14

Wardaugh, Ronald. (1986). An Introduction to Sociolinguistics. Massachusetts: Basil Blackwell Ltd. 